\title{
The Australian Economy in 2017-2018: The Importance of Stronger Non-Mining Business Investment Growth
}

Tim Robinson and Jiao Wang*

* Robinson and Wang: Melbourne Institute of Applied Economic and Social Research, The University of Melbourne, Victoria 3010 Australia. Corresponding author: Robinson, email <tim.robinson@unimelb.edu.au>. The authors thank Viet H. Nguyen for his assistance, and Ian McDonald, Ross Williams and Guay Lim for their useful comments. This work was supported by ARC DP 160102654.

This is the author manuscript accepted for publication and has undergone full peer review but has not been through the copyediting, typesetting, pagination and proofreading process, which may lead to differences between this version and the Version of Record. Please cite this article as doi: $10.1111 / 1467-8462.12257$

This article is protected by copyright. All rights reserved 


\section{Introduction}

Growth in the Australian economy slowed in 2016-2017. This, however, was influenced by temporary supply disturbances, namely adverse weather conditions, with smaller contribution from trade to growth. This masked some positive trends that emerged, such as growth in domestic final demand strengthening. Output growth in 2017-2018 is likely to be stronger, partially reflecting these past supply disturbances, together with a gradual further strengthening of domestic final demand growth (see Table 1).

The traded sector is likely to continue contributing to overall output growth in 2017-2018, with further growth in exports of liquefied natural gas (LNG) representing an important factor. However, in 2018-2019 this expansion in LNG production will finish and the impetus to exports growth from the mining boom will be over.

Growth in residential investment slowed considerably in 2016-2017, and is likely to slow further in 2017-2018. Assuming wages growth improves only modestly, it is difficult to see a step up in consumption growth. Consequently, the prospects for non-mining business investment are of key importance for the overall outlook. While still highly uncertain, encouragingly these have improved recently.

As in recent years, a key source of risks to this outlook, however, is the prospects for the Chinese economy.

Low inflation persisted in 2016-2017. Wages growth remained weak, despite further improvements in the labour market. This low inflation environment contributed to monetary policy being unchanged, and hampered fiscal revenues. The Reserve Bank Governor noted that the Board '.. has been conscious that a balance needs to be struck between the benefits of monetary stimulus and the medium-term risks associated with rising levels of debt relative to our incomes' (Lowe 2017).

Looking forward, the improvement in the real side of the economy may be accompanied by higher inflation and wages growth. Any such increase, however, appear likely to be modest. Consequently, in the near-to-medium term monetary policy may remain accommodative.

The structure of this article is as follows. In Section 2 we discuss international economic developments of importance for Australia, with an emphasis on the Chinese economy and its prospects. We also discuss developments in both the terms of trade and the real exchange rate. Section 3 summarises developments in the real economy and inflation, together with developments in labour and financial markets. Particular attention is paid to the outlook for non-mining investment growth. Section 4 concludes the article.

\section{International Influences}

The global economy gained momentum in 2016-2017. The International Monetary Fund (IMF) forecasts global economic growth in 2017 to be 3.6 per cent, up by 0.2 percentage points from forecasts made in the October World Economic Outlook last year (IMF 2017b). A small further increase in growth is expected in 2018, reaching 3.7 per cent (see Figure 1). The upswing in growth has been broad-based, although low wages growth has also been evident in several 
countries, creating uncertainty about the prospects for consumption, and hence output, growth. The medium-term growth prospects in many nations remain below their pre-crisis average growth rates.

\subsection{The United States}

The IMF expects the US economy to grow solidly, namely by 2.2 per cent in 2017 and by 2.3 per cent in 2018 (IMF 2017b), contributing to the improvement in global growth prospects. The strengthening outlook reflects favourable financial conditions and strong business and consumer confidence.

The US labour market continues to improve, with the unemployment rate reaching a new low since the global financial crisis, averaging 4.5 per cent in the first three quarters of 2017 (Figure 2). The participation rate, on the other hand, has been stable at a low level, averaging 62.9 per cent in the first three quarters of 2017, which is only slightly higher than its average in 2016. A considerable amount of the fall in the participation rate, however, is likely to be structural, for example, due to the aging of the population. Sluggish growth in total factor productivity has been weighing on US output growth and may continue to do so in the medium term.

The Federal Reserve has, so far, increased interest rates twice this year, taking the federal funds rate to 1.25 per cent. These increases were motivated by a continuously strengthening labour market and stable inflation, with a further increase expected in December. The recovery of the US economy has prompted the Federal Reserve to announce, in September, a gradual process of unwinding its large balance sheet, accumulated through the unconventional monetary policy conducted during the global financial crisis.

\subsection{Europe}

The IMF expects output growth in the Euro Area to strengthen in 2017 to 2.1 per cent, before moderating slightly to 1.9 per cent in 2018 (IMF 2017b). The expected improvement comes from a pick-up in export demand as well as a firming of domestic-demand growth in several Euro member countries (see Figure 3).

The unemployment rate in the Euro Area continued to improve in 2016-2017. In October 2017 it was 8.8 per cent, compared to around 10 per cent a year ago. Nevertheless, monetary policy in the Euro Area is expected to remain accommodative in 2018, helping to support area-wide activity. The European Central Bank (ECB) announced it would aim to halve its monthly net asset purchases in 2018 to a monthly pace of $€ 30$ billion by the end of September, although this is subject to developments in economic outlook and financial conditions.

Growth in the United Kingdom is projected to reach 1.7 per cent in 2017 and 1.5 per cent in 2018 (IMF 2017b). The projection for 2017 is 0.6 percentage points higher than that made a year ago. Higher inflation prompted the Bank of England to tighten monetary policy in November 2017 for the first time in 10 years, unwinding the Brexit-related cut of last year. Nevertheless, monetary policy remains highly accommodative, with the policy rate at 0.5 per cent. Economic policy uncertainty has decreased since the Brexit decision, but remains considerable, with many of the details of its implementation still yet to be determined. ${ }^{1}$

\subsection{Japan}

This article is protected by copyright. All rights reserved 
In Japan, output growth is projected to be a relatively strong 1.5 per cent in 2017 . This strength is in part due to improved foreign demand, especially from Asian markets. Monetary policy remains expansionary, fiscal policy supportive and the consumption tax increase scheduled for April 2017 was postponed until 2019. Inflation has improved, but remains weak. Prime Minister Shinzo Abe was re-elected in October, signalling a continuation of Abenomics. The IMF expects slower growth in 2018 (0.7 per cent), with less support from fiscal policy, and population aging continuing to weigh on potential output growth (IMF 2017b). The IMF has noted a need for further structural reforms and advocate for a '.. clear and credible mediumterm fiscal consolidation plan' to address Japan's high level of public debt (IMF 2017a).

\subsection{China}

The IMF revised its projection of growth in China in 2017 up by half a percentage point to 6.7 per cent, due largely to the stronger-than-expected economic performance in the first half of 2017 driven by continuing policy effects and supply-side reforms. In 2018, growth is forecast to slow to 6.5 per cent.

Expansionary fiscal policy, mostly through public investment, is expected to persist in 2018 or longer, in order to meet the official target of doubling the 2010 level of real output by 2020 . Economic growth is expected to also be supported by further supply-side reforms. The latter is to encourage the so-called 'high-quality' growth that was highlighted in the report delivered to the 19th National Congress in October. The economic policy in the report includes a commitment to develop national infrastructure, urbanisation and environment protection.

Concerns regarding an oversupply of housing has prompted the introduction of policies in recent years to reduce the level of inventories. However, property prices in Tier 1 cities (such as Beijing) grew very strongly, and consequently policies targeting particular cities were introduced in response. Price growth in Beijing, for example, has slowed markedly (see Figure 4). The most recent policies, introduced in September and October 2017, were focused on curbing speculative real-estate investment, and are likely to further weigh on price growth going forward.

China's credit and financial risks continued to intensify in 2017. Non-financial sector credit to GDP ratio reached 257 per cent in the March quarter, with credit to non-financial corporations amounting to 165 per cent of GDP (see Figure 5). The rising leverage ratio combined with the diminished fiscal space available, in case of disruptive adjustment, has caused serious concerns among Chinese authorities. Proactively preventing systemic risks was a top priority in the 19th National Congress report. In early 2017 the People's Bank of China (PBoC) included offbalance sheet Wealth Management Products (WMPs) into its Macro Prudential Assessment framework. This is the first time the PBoC has officially attempted to regulate shadow-banking activities in China.

In early 2017, the PBoC tightened monetary policy by increasing its seven-day repo rate twice by 10 basis points and clarified that the policy stance had now returned to neutral. Inflation rose to 2 per cent in 2016 and is expected to remain stable at around 2 per cent in 2017. The renminbi has appreciated in 2017 to date, with tighter management of capital flows, a weaker US dollar, and a stronger near-term growth outlook all probably contributing.

\subsection{Terms of Trade and Exchange Rate}


One of the main ways in which global developments have influenced the Australian economy for more than a decade has been fluctuations in the terms of trade, namely the ratio of export to import prices (see Figure 6). The development of China, and its effect on the demand for Australian resource exports, has underpinned the behaviour of the terms of trade. In the September quarter 2017 the terms of trade were 24 per cent below their September quarter 2011 peak.

Bulk commodity prices have been volatile in 2017. In the March quarter the adverse impact of cyclones in Queensland on coking coal supply boosted prices, although subsequently they have declined. A pick-up in global demand for commodity exports, stronger-than-expected Chinese steel production, together with a global iron ore production supply ramping up more slowly than expected, may have supported bulk commodity prices (RBA 2017c).

On the other hand, factors such as China's planned steel production cuts during the winter months to reduce air pollution and structural reform of the industry have placed downward pressure on the bulk commodity prices in 2017-2018 to date and this is likely to continue (RBA 2017c). In the medium term, growth in Chinese demand for iron ore and coking coal, the two key inputs in steel production, is likely to slow, in part due to a policy-related slowing in construction (see Office of the Chief Economist 2017); environmental protection was also an aspect of the report delivered to the National Congress. However, growth in steel production may be stronger in some other developing countries, such as India (Office of the Chief Economist 2017).

\section{Australia}

\subsection{Economic Activity}

In recent years, the Australian economy has been characterised by insipid domestic final demand growth, with overall output growth supported by the contribution from net exports (see Figure 7). There were some changes to these trends in 2016-2017. In particular, domestic final demand growth lifted and the contribution from net exports, while still sizeable, decreased.

\subsubsection{Domestic Final Demand}

The lift in domestic final demand occurred despite consumption growth slowing (see Figures 7 and 9). Weak wages growth has restrained household income growth, despite the labour market otherwise generally improving. While the household saving ratio moved lower (see Figure 8), households generally remain cautious, with consumer sentiment at a below-average level.

A key dimension in the post-mining boom transition has been strong residential investment growth supporting domestic final demand growth (see Figure 9). In 2016-2017 this slowed markedly - its growth was around 1.6 per cent, compared with 10.5 per cent in 2015-16. The slowing in part reflects the adverse weather conditions hampering construction in the March quarter, but also simply that the past rates were unsustainable. Much of the growth was concentrated in apartment construction and concerns exist regarding an oversupply in some markets, such as Brisbane (see Robinson, Nguyen and Wang 2017). A further contributing factor may have been the macroprudential policies implemented by the Australian Prudential Regulatory Authority (APRA), some of which had a focus on growth in investor credit. Kearns 
(2017) notes that tighter management of capital flows in China may have resulted in less demand from foreign purchasers of new properties.

The prospects are that residential construction will slow further, and could subtract from output growth in 2017-2018. Encouragingly, however, any subtraction may only be small; a leading indicator for residential construction, namely dwelling approvals, shows that approvals for detached houses were around 3.1 per cent higher over the year to September 2017, whereas apartments were more than 15 per cent lower (see Figure 10).

Public demand contributed positively to growth in 2016-2017, due both to public consumption and investment. Growth in the latter picked up noticeably, and the RBA notes that infrastructure spending has been an important factor, which is likely to continue to be the case in 2017-2018 (RBA 2017c). This will provide some offset to the likely subtraction to growth from residential investment; Ellis (2017) notes that the '... spillovers to the rest of the economy probably are stronger than for housing', for example, by boosting private sector productivity. Ellis also argues that this is particularly the case for transport infrastructure, which in the current episode is playing a larger role than it did in the previous upswing in public infrastructure spending.

Strong growth in mining investment occurred as firms expanded their capacity in response to high commodity prices. Following the peak in the terms of trade in 2011, mining investment has fallen considerably; the level of real mining investment in 2016-2017 was 60 per cent lower than its peak in 2012-2013. Despite the mining sector being only around 7 per cent of nominal gross value added, it is highly capital intensive, and these falls have weighed on overall output growth.

An encouraging development in 2016-2017 was that the pace of decline in nominal mining investment slowed, and it appears that the drag is likely to be slight going forward. The Australian Bureau of Statistics Capital Expenditure Survey (CAPEX), which records firms' nominal investment intentions, suggests that much of the adjustment has occurred (see Figure 11); the RBA has also expressed similar sentiments (see, for example, Lowe 2017).

\subsubsection{Non-Mining Business Investment}

Despite these positive developments in mining investment, with consumption growth likely to strengthen only gradually and residential investment to soften, the outlook for non-mining business investment is of critical importance to support overall output growth.

In recent years, non-mining business investment has been the disappointing component of the post-mining boom adjustment. While many reasons have been given for its weakness - such as firms using high hurdle rates or heightened levels of uncertainty (Kent 2014) - it has been difficult to ascertain their relative importance. Debelle (2017) provides a recent review of these potential factors and highlights the role of expectations of future demand; see also Australian Government and Heads of Treasuries (2017).

In 2016-2017 nominal non-mining business investment grew modestly, and investment intentions, as measured by the CAPEX survey, point to sizeable growth in 2017-2018 (see Figure 11). This is the fourth estimate, by which point these intentions usually become more reliable. Coverage issues (such as not including the health sector), mean the CAPEX survey is 
not as reliable for non-mining compared to the mining sector (see Berkelmans and Spence 2012). The RBA, however, has noted that stronger investment intentions exist in the sectors not covered by the survey (RBA 2017a).

The CAPEX survey is not the only positive indicator. Business conditions, as measured by the NAB Monthly Business Survey, are at well above-average level; the more forward-looking business confidence measure is weaker, but it is also optimistic (see Figure 12). A caveat to this is that business confidence being above-average is not a new development; it has existed for several years. This strength is in contrast to the below-average consumer sentiment which occurred in 2016-2017 (see Figure 12). There are several possible reasons for this divergence, including the low wage environment, and that interest rate increases by banks independent of the RBA have been borne primarily by households (particularly investors).

A further factor that may support the outlook for non-mining investment is that economic policy uncertainty in Australia has declined in 2017 to date, and is at a relatively low level. ${ }^{2}$

An indicator suggesting that non-mining investment is strengthening is that growth in capital imports has improved (see Figure 13). However, capital imports are volatile and their relationship with investment is loose. A less optimistic indicator is business credit; which is growing modestly (see Figure 14). One possibility is that this partially reflects improved profitability in the non-mining sector.

In all, there are some positive signals about the outlook for non-mining business investment, although it is far from certain.

\subsubsection{Trade}

The last phase of a mining boom is when the expansion in capacity becomes productive (see, for example, Plumb, Kent and Bishop 2013). Australia has now been in this phase for several years. In 2016-2017 resource exports were disrupted by bad weather, and consequently some of the growth in 2017-2018 anticipated by the Office of the Chief Economist at the Department of Industry reflects a recovery (particularly for metallurgical coal). The level of metallurgical coal exports forecast for 2018-2019 is only modestly higher than that in 2015-2016; for thermal coal it is actually lower. While growth in Australia's largest export, iron ore, is anticipated to continue, the component that is forecast to increase strongly is LNG (see Figure 15). By the end of 2018-2019, however, this will probably have run its course and the production phase of the resources boom will draw to a close. Debelle (2017) notes that at this time the value of LNG exports will be around 15 per cent of Australia's total exports.

Recently, outside commodity exports, growth in rural exports has been strong, although they are volatile. Growth in service exports, the second biggest category of Australian exports, has eased, but remains robust, whereas manufactures barely increased. Ellis (2017) notes that sectors that were adversely affected by the real appreciation during the mining boom could contribute to growth going forward.

For several years imports growth was anaemically weak. Encouragingly, in 2016-2017, this changed, with the strengthening partially reflecting the pick up in domestic final demand growth (see Figure 16), which together with the real exchange rate is one of the fundamental determinants of imports. In addition to the increase in capital imports, the other categories of imports, namely intermediate goods (the largest category) and services have also improved. 


\subsection{Labour}

The Australian labour market improved in 2016-2017. The unemployment rate decreased from an average of around 5.9 per cent in 2015-2016 to 5.5 per cent (see Figure 17) in November 2017. The participation rate, namely the share of the working-age population in the labour force, has also recently improved. ${ }^{3}$ Recent estimates from the Reserve Bank of Australia (Cusbert 2017) that the Non-Accelerating Inflation Rate of Unemployment (NAIRU) currently is around 5 per cent, which suggests that only modest labour market slack exists (although considerable uncertainty surrounds these estimates).

A concern has been that focussing on the unemployment rate may produce an overly optimistic reading of the state of the labour market due to increased labour underemployment, namely people working fewer hours than they desire. In 2016-2017 the underemployment rate (which includes both those that are employed, but underutilised, and the unemployment) increased, particularly for those aged 15 to 24, although subsequently the total underutilisation rate has ticked down (see Figure 18).

It should be noted that this measure of underutilisation is heads-based, that is, it is a count of the number of people working fewer hours than they desire. The RBA, using ABS data, has alternatively constructed a time series of volume measures of labour underutilisation (see RBA 2017b; Lowe 2016). These volume measures are much more highly correlated with the unemployment rate than the heads-based series. One interpretation could be that a greater share of people are underemployed than previously, but the extent of underemployment is small.

Another indication that labour underutilisation may be becoming less prevalent has been a shift in the composition of employment growth towards full, rather than part-time, employment (see Figure 19).

Turning to the trends in employment across the sectors, between August 2016 and August 2017 the largest increases were in the health care and social assistance and construction industries (see Table 2). In both of these sectors the new jobs were overwhelmingly in full-time positions, and were mainly for the age groups 15-24 and 25-44 (see Table 3). Employment in the education sector also posted a sizeable increase, with an even split between full- and part-time jobs and a larger share for those aged 45-59. On the flipside, the largest declines were in the professional, scientific technical services, and administrative and support services.

\subsection{Wages and Inflation}

Wages growth has remained anaemic despite improvements in the labour market (see Figure 20). In particular, growth in the Wage Price Index - the main measure focused on by policymakers - remained around its lowest rate since its inception in the late 1990s. Besides slack in the labour market, several other factors potentially are important determinants of the low wages growth. The first is that inflation expectations are very low. This is evident in a variety of measures (relative to their respective means); examples include the Melbourne Institute measure and that implied by the difference between indexed and nominal bonds (see Figure 21).

A second factor is that trend labour productivity growth has slowed. Supply-side policies intended to boost productivity growth could support wages growth in the medium term. Wages 
normalised by productivity, namely unit labour costs, are an important determinant of inflation. In recent years there has been little growth in unit labour costs (see Figure 22). Similarly, low inflation, also occurring in Australia's major trading partners, together with a modest appreciation of the nominal exchange rate in 2016-2017, has resulted in negligible growth in import prices, the other key determinant of inflation.

Underlying inflation remained below the RBA's target band of over 2-3 per cent in 2016-2017 (see Figure 23). Real wages, deflated by underlying inflation, grew only slightly during this period. More recently, headline inflation has moved higher, to around 2 per cent. Higher petrol prices may boost headline inflation in the near term. It seems likely that underlying inflation will remain subdued and drift up only gradually, primarily reflecting the prospects for wages and low inflation expectations.

\subsection{Financial Markets, Macroprudential and Monetary Policies}

In an economy with low wages growth, subdued inflation and domestic final demand growth there was little impetus for a change in monetary policy settings. As discussed previously, actual interest rates faced by households did change, with increases particularly for investor mortgages (see Figure 24). Alternatively, rates for small businesses have been little changed.

The increases in interest rates for investor mortgages partially reflect a tightening of macroprudential policies. Australia's macroprudential policies have been primarily targeted at the investor segment of the housing market, and include limiting investor credit growth to less than 10 per cent (see Figure 25).

The most recent policy move by APRA in March 2017 was intended to slow the growth in interest-only loans. These are particularly appealing to investors as interest payments can be claimed back as a tax expense on investment properties and they potentially allow for more borrowing. Such mortgages were limited to 30 per cent of new mortgage lending, with additional limits introduced on those with high loan-to-value ratios. The RBA has noted that there has been a sharp drop in loan approvals, particularly for interest-only loans (RBA 2017c; see also Kohler 2017). While investor credit growth is higher than it was a year ago, it remains considerably slower than the growth rates reached in 2014 before the first of the macroprudential policy measures (see Figure 25). In all, it appears that these policies are helping to moderate risks to the outlook stemming from the quality of residential mortgages.

One issue is what level the policy rate will eventually return to when monetary policy begins to be tightened, that is, when it becomes appropriate to shift from the current expansionary policy settings. This has the potential to influence activity today when agents are forwardlooking. Put another way, the issue is what the neutral interest rate is, that is, the rate that is neither stimulatory nor contractionary on the economy.

The neutral real rate is unobserved, and must be estimated. The Reserve Bank released research which estimated that the neutral real rate had declined to around 1 per cent now, which is around 150 basis points lower than before the financial crisis (McCririck and Rees 2017). This estimate, combined with the inflation target, suggests that the neutral nominal rate is around 3.5 per cent. The main factors attributed to driving this decline were a decline in potential growth and heightened risk aversion. ${ }^{4}$

Long yields in Australia also remain low by historical standards, but they are higher than the low levels reached last year. Encouragingly, the spread to short rates has increased, which may signal financial markets becoming more optimistic about the economic outlook in Australia. 


\subsection{Residential Property Prices}

House price growth, in aggregate, remained strong in 2016-2017 (see Figure 26). Substantial differences, however, existed across the capital cities, with strong growth in Sydney and Melbourne contrasting with ongoing (although diminishing) falls in Perth. The latter reflects the commodity price falls, and their associated impact on household incomes and population growth. More recently, slowing growth has been evident in Sydney, whereas Melbourne prices have performed more strongly, in part due to the particularly strong population growth (see Figure 27). ${ }^{5}$

Growth in the prices of attached dwellings, such as apartments, slowed slightly in 2016-2017 (see Figure 26). Like house prices, there has been substantial variation across the capitals, with the strongest growth in Sydney. While Perth prices continued to fall, declines occurred in Brisbane for the first time in 2016-2017, with strong growth in the supply of inner city apartments a likely contributing factor. More recently, a softening has been evident in the Sydney market; for example, auction clearance rates have moved lower.

\section{Concluding Remarks}

The Australian economy has been heavily influenced by the terms of trade and the associated mining boom in the past decade. It appears that many of these influences are diminishing and will largely come to an end in 2018-2019.

Growth slowed in 2016-2017, in part due to temporary supply-side disruptions, namely adverse weather in the March quarter. While this slowing is likely to be reversed in 2017-2018, a greater issue is the outlook for the medium term. At this time residential investment is likely to be subtracting from growth, and if accompanied by only a gradual increase in wages growth it is hard to see a rapid strengthening in consumption growth. For these reasons it is particularly important that there be a sizeable, ongoing upswing of non-mining business investment. Encouragingly, there have been some positive developments, most notably the strengthening in the CAPEX survey, but the outlook remains uncertain.

The medium-term growth prospects, together with the outlook for real wages growth, could be enhanced by supply-side policies intended to boost Australia's productivity growth.

As in previous years, the main risk to Australia's growth prospects is the possibility of financial instability in China and its associated negative impacts on growth in the Chinese economy.

Overall, a pick-up in growth appears likely in 2017-2018, although this is partially due to the past supply disturbances with domestic demand growth expected to increase only modestly. Uncertainty, however, exists about whether this momentum in output growth will be maintained in the medium term.

December 2017 


\section{Endnotes}

${ }^{1}$ As measured by <http://www.policyuncertainty.com>. See Baker, Bloom and Davis (2016).

${ }^{2}$ As measured by <http://www.policyuncertainty.com>. See Baker, Bloom and Davis (2016).

${ }^{3}$ For a further discussion of trends in labour force participation see Ellis (2017).

${ }^{4}$ McCririck and Rees (2017) present an unobserved components model comprised of an IS curve, an Okun's law equation and a Phillips curve. Output is assumed to be $\mathrm{I}(2)$, that is, the trend growth rate follows a random walk. The neutral real rate is a sum of the (annualised) trend growth rate and an unobserved random walk component, similar to Holston, Laubach and Williams (2016).

${ }^{5}$ See RBA (2017c) for a discussion of the relative importance of overseas and interstate migration. 


\section{References}

Australian Government and Heads of Treasuries 2017, Intergovernmental Review of Business Investment, September 2017,

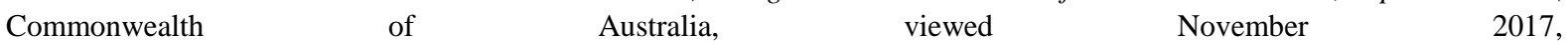
<https://cdn.tspace.gov.au/uploads/sites/107/2017/10/HoTs_B_Investment.pdf〉.

Baker, S. R., Bloom, N. and Davis, S. J. 2016, 'Measuring economic policy uncertainty', Quarterly Journal of Economics, vol. 131, pp. 1,593-636.

Berkelmans, L. and Spence, G. 2013, 'Realisation ratios in the Capital Expenditure Survey', Reserve Bank of Australia Bulletin, December, pp. 1-6.

Cusbert, T. 2017, 'Estimating the NAIRU and the unemployment gap', Reserve Bank of Australia Bulletin, June, pp. 13-22.

Debelle, G. 2017, 'Business investment in Australia', speech to UBS Australasia Conference 2017, Sydney, 13 November, viewed November 2017, <http://www.rba.gov.au/speeches/2017/sp-dg-2017-11-13.html>.

Ellis, L. 2017, 'Where is the growth going to come from?', Stan Kelly Lecture, Melbourne, 15 November, viewed November 2017, <http://www.rba.gov.au/speeches/2017/sp-ag-2017-11-15.html>.

Holston, K., Laubach, T. and Williams, J. C. 2016, 'Measuring the natural rate of interest: International trends and determinants', Federal Reserve Bank of San Francisco Working Paper no. 2016-11.

International Monetary Fund (IMF) 2017a, Japan: 2017 Article IV Consultation, IMF Country Report no. 17/242, IMF, Washington, DC.

International Monetary Fund (IMF) 2017b, World Economic Outlook, October, IMF, Washington, DC.

Kearns, J. 2017, ‘Australian property - Financial stability and foreign involvement', speech at Aus-China Property Developers, Investors \& Financiers, Sydney, viewed November 2017, <https://www.rba.gov.au/speeches/2017/sp-so-2017-11-20.html>.

Kent, C. 2014, 'Non-mining business investment - Where to from here?', address to Bloomberg Economic Summit, Sydney, 16 September, viewed December 2016, <http://www.rba.gov.au/speeches/2014/spag-160914.html>.

Kohler, M. 2017, 'Mortgage insights from securitisation data', speech to Australian Securitisation Forum, Sydney, 20 November, viewed November 2017, <http://www.rba.gov.au/speeches/2017/sp-so-dm-2017-11-20.html>.

Lowe, P. 2016, 'Inflation and monetary policy', address to Citi's 8th Annual Australia and New Zealand Investment Conference, Sydney, 18 October, viewed November 2017, <http://www.rba.gov.au/speeches/2016/sp-gov-2016-10-18.html>.

Lowe, P. 2017, 'Opening statement to the House of Representatives Standing Committee on Economics', Melbourne, 11 August, viewed November 2017, 〈http://www.rba.gov.au/speeches/2017/sp-gov-2017-08-11.html>.

McCririck, R. and Rees, D. 2017, 'The neutral interest rate', Reserve Bank of Australia Bulletin, September, pp. 9-18.

Office of the Chief Economist 2017, Resources and Energy Quarterly, Department of Industry, Innovation and Science, September, Canberra.

Plumb, M., Kent, C. and Bishop, J. 2013, 'Implications for the Australian economy of strong growth in Asia', Reserve Bank of Australia Research Discussion Paper no. 2013-03, Sydney.

Reserve Bank of Australia (RBA) 2017a, 'Minutes of the Monetary Policy Meeting of the Reserve Bank Board', September, viewed November 2017, <http://www.rba.gov.au/monetary-policy/rba-board-minutes/2017/2017-09-05.html>.

Reserve Bank of Australia (RBA) 2017b, Statement on Monetary Policy, February, Sydney.

Reserve Bank of Australia (RBA) 2017c, Statement on Monetary Policy, November, Sydney.

Robinson, T., Nguyen, V. H. and Wang, J. 2017, 'The Australian economy in 2016-17: Looking beyond the apartment construction boom', Australian Economic Review, vol. 50, pp. 5-20. 
Figure 1 Global Growth (\%)

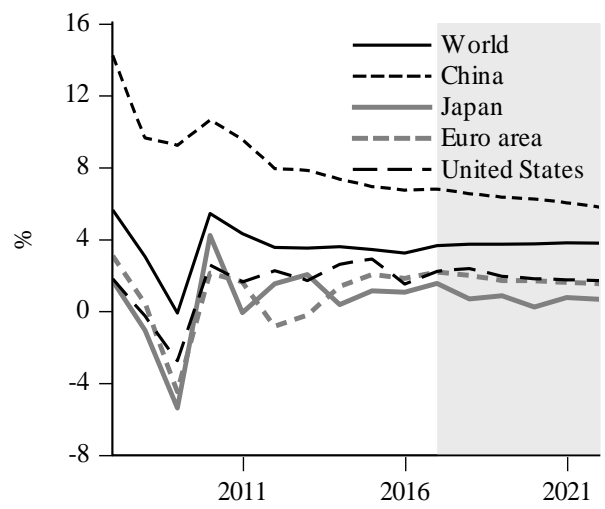

Note: Grey area represents IMF forecasts

Source: IMF (2017b)

Figure 2 US Unemployment Rate and Participation Rate Monthly (\%)

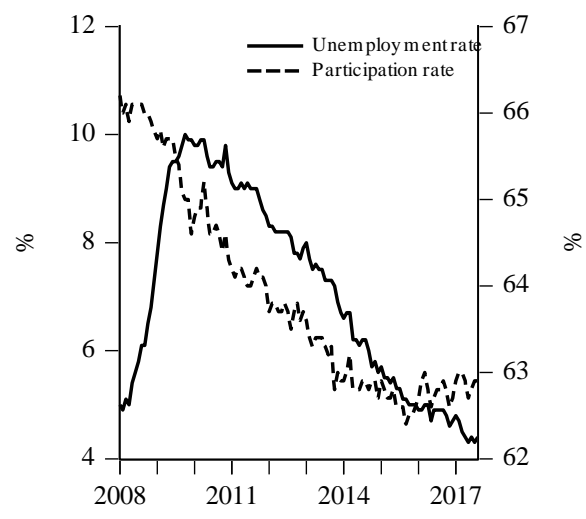

Source: Federal Reserve Bank of St. Louis

Figure 3 Growth in Europe (\%)

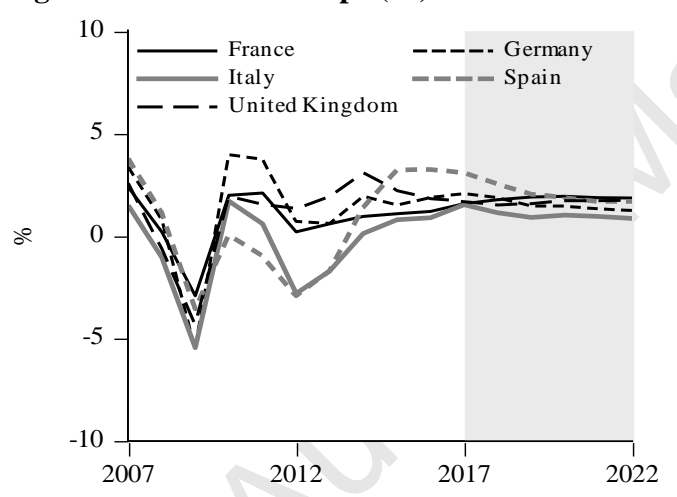

Note: Grey area represents IMF forecasts

Source: IMF (2017b) 
Figure 4 China's Residential Property Price for Beijing, Index, 2015=100

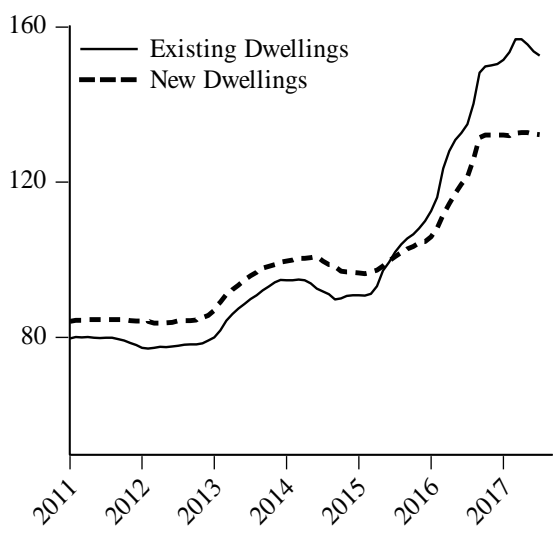

Source: National sources, BIS Residential Property Price database

Figure 5 China's Credit as Percentage of GDP

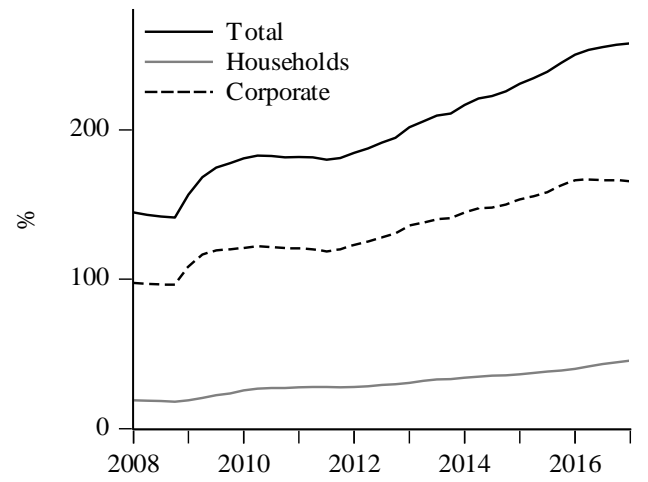

Source: Bank for International Settlements

Figure 6 Australia's Terms of Trade and Real Exchange Rate, Quarterly

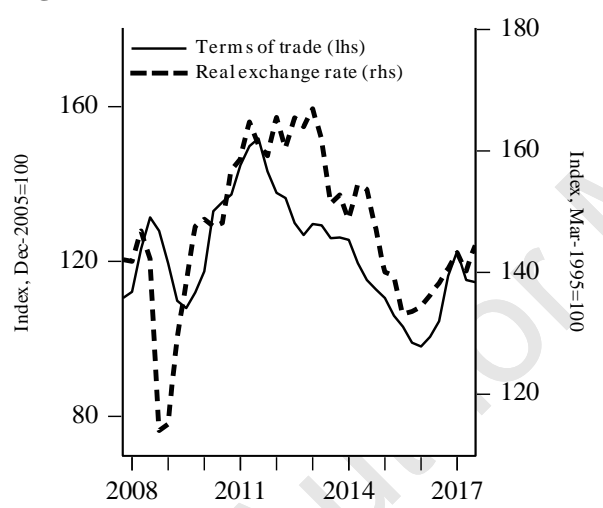

Sources: Australian Bureau of Statistics, Reserve Bank of Australia 
Figure 7 Real GDP and Domestic Final Demand Growth (Year-Ended)

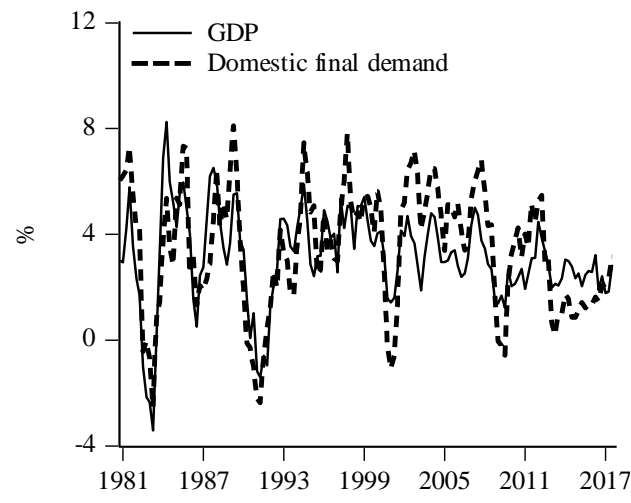

Source: Australian Bureau of Statistics

Figure 8 Trend Household Saving Ratio

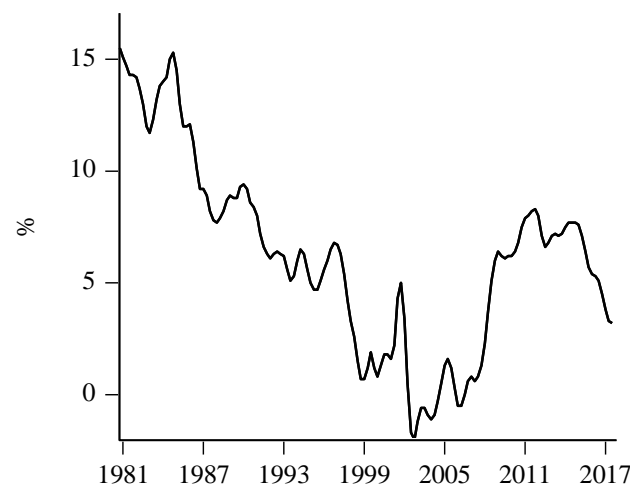

Source: Australian Bureau of Statistics

Figure 9 Real Household Consumption and Residential Investment Growth (Year-Ended)

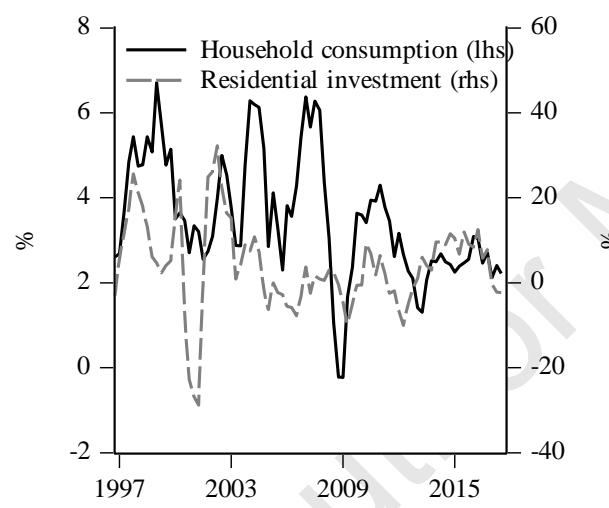

Source: Australian Bureau of Statistics 
Figure 10 Trend Private Dwelling Approvals

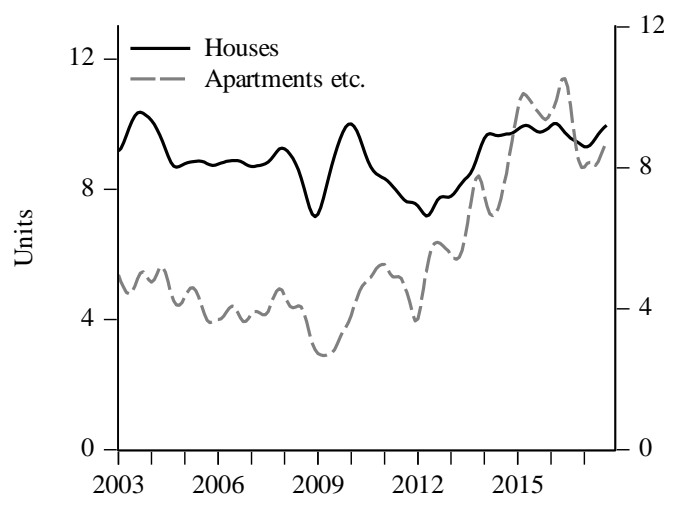

Source: Australian Bureau of Statistics

Figure 11 Investment Intentions

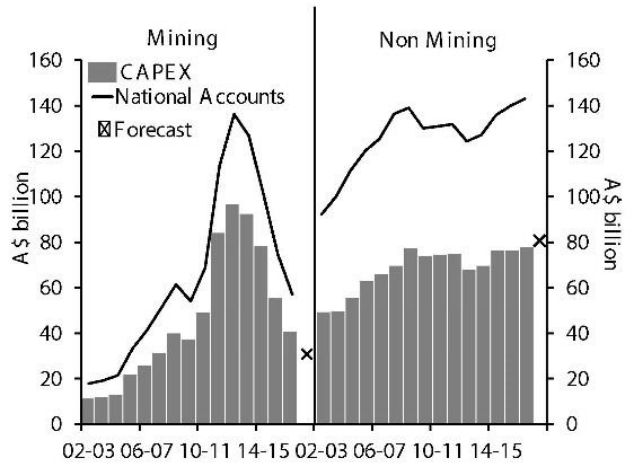

Sources: Australian Bureau of Statistics, Melbourne Institute 
Figure 12 Consumer Sentiment and Business Conditions
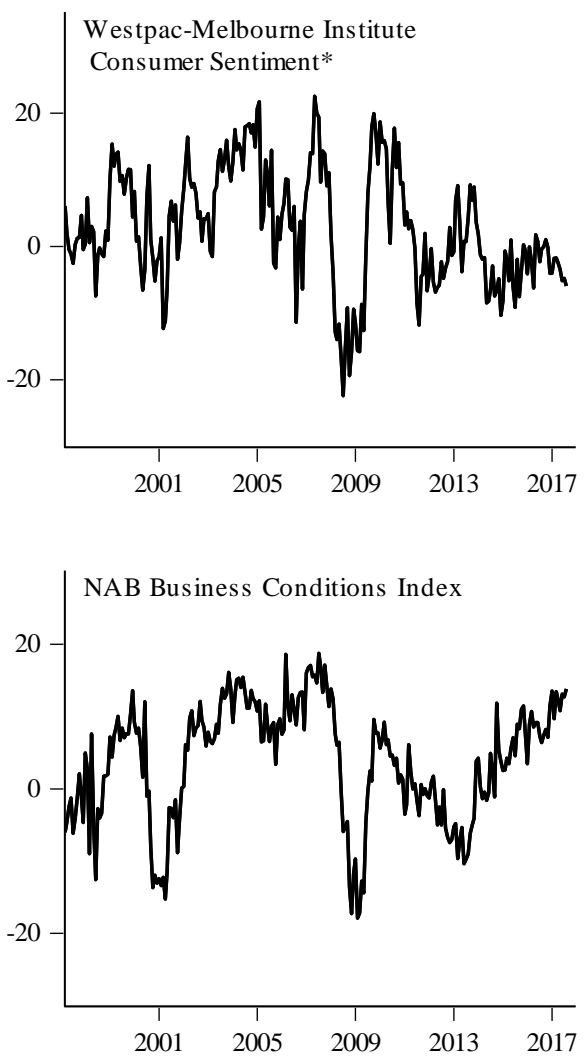

Note: * Deviation from long-run average

Sources: Melbourne Institute, Reserve Bank of Australia

Figure 13 Capital Imports Growth (Year-Ended, \%)

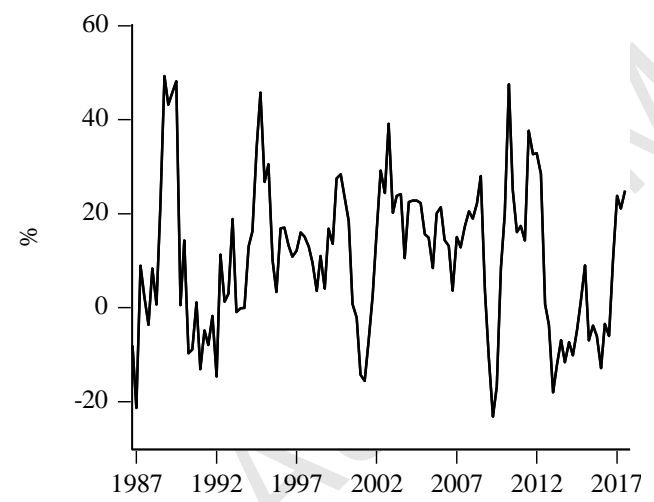

Source: Reserve Bank of Australia 
Figure 14 Business Credit Growth (Year-Ended, \%)

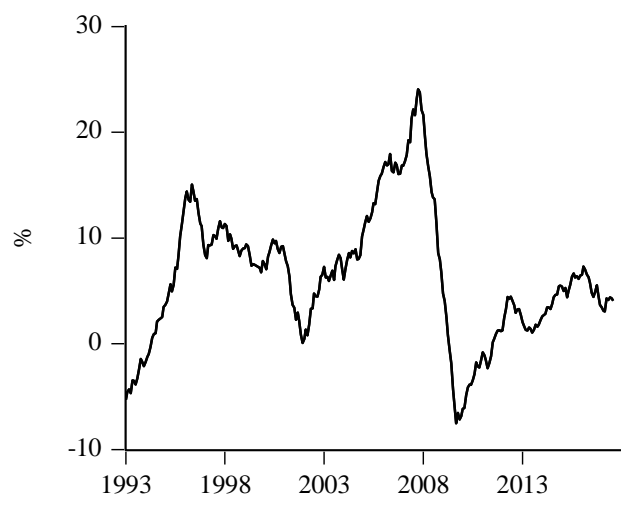

Source: Reserve Bank of Australia

Figure 15 Iron Ore and Liquefied Natural Gas (LNG) Exports (MT)

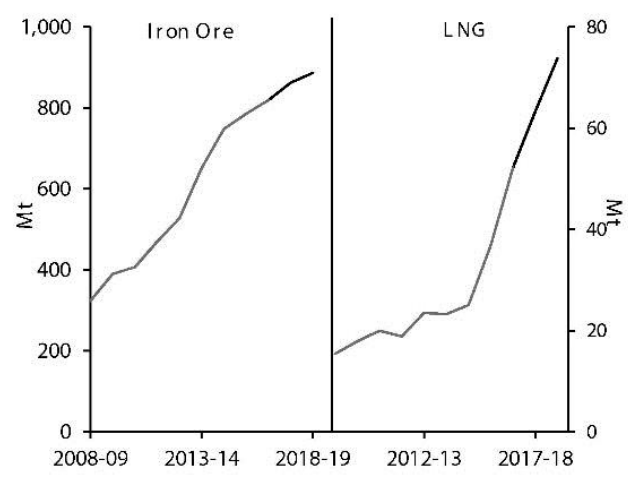

Note: Includes forecasts for 2017-18 and 2018-2019 (black)

Source: Office of the Chief Economist (2017)

Figure 16 Imports and Domestic Final Demand Growth (Year-Ended)

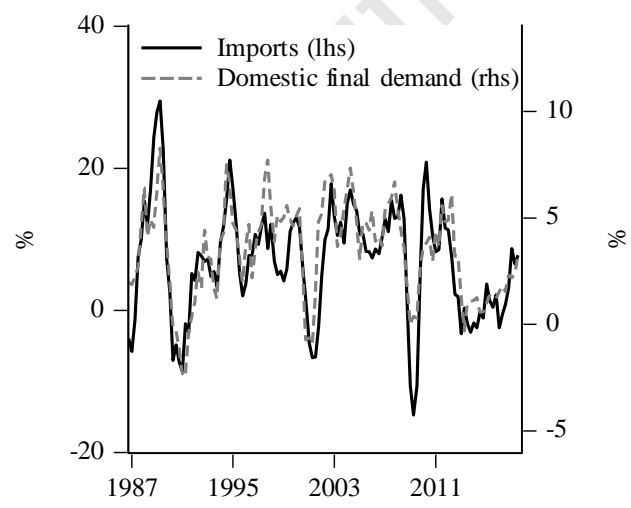

Source: Australian Bureau of Statistics

This article is protected by copyright. All rights reserved 
Figure 17 Unemployment and Participation Rate (Trend, \%)

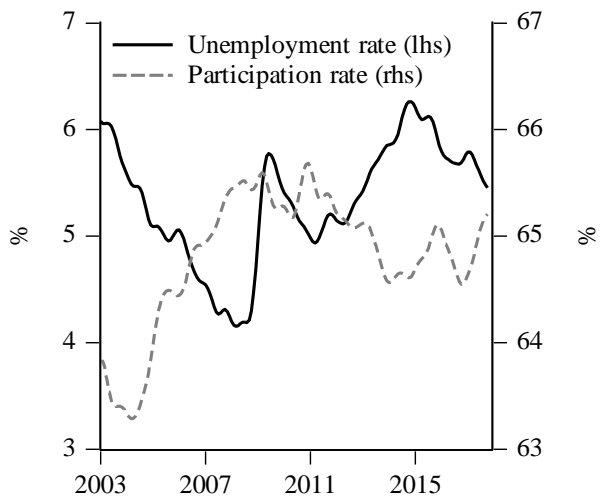

Source: Australian Bureau of Statistics

Figure 18 Labour Underutilisation Rate (Trend, \%)

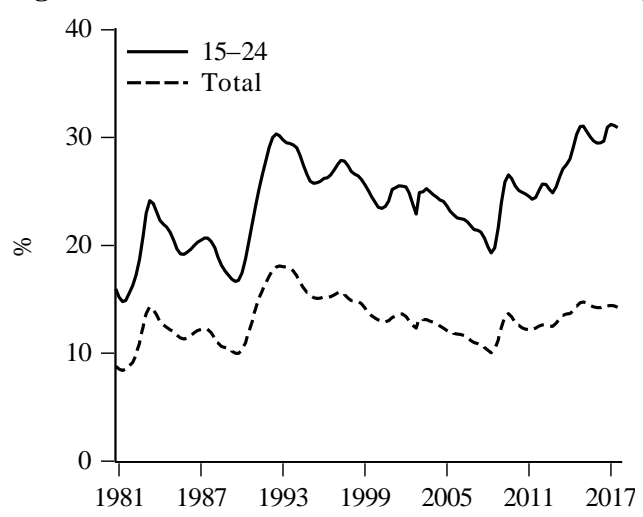

Source: Australian Bureau of Statistics

Figure 19 Employment Growth (Trend, \%)

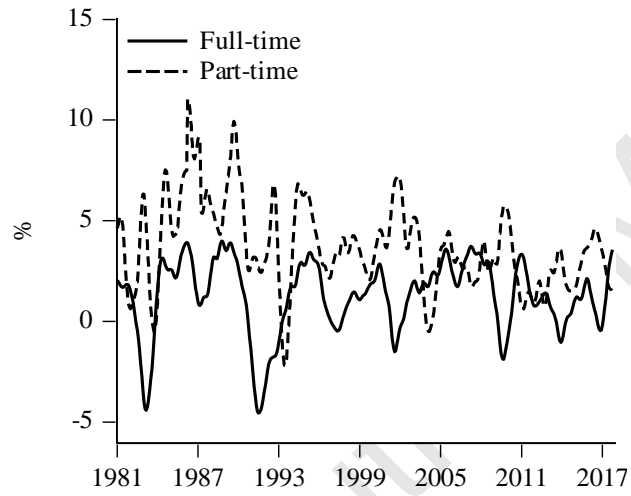

Source: Australian Bureau of Statistics 
Figure 20 Wage Price Index Growth (Year-Ended, \%)

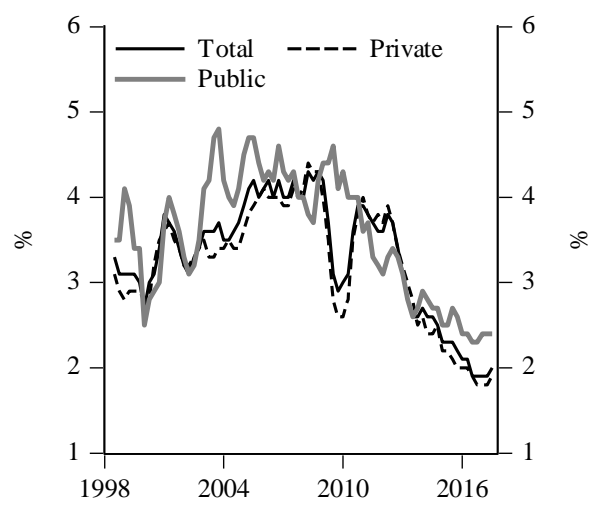

Source: Australian Bureau of Statistics

Figure 21 Inflation Expectations (Year-Ended, \%)

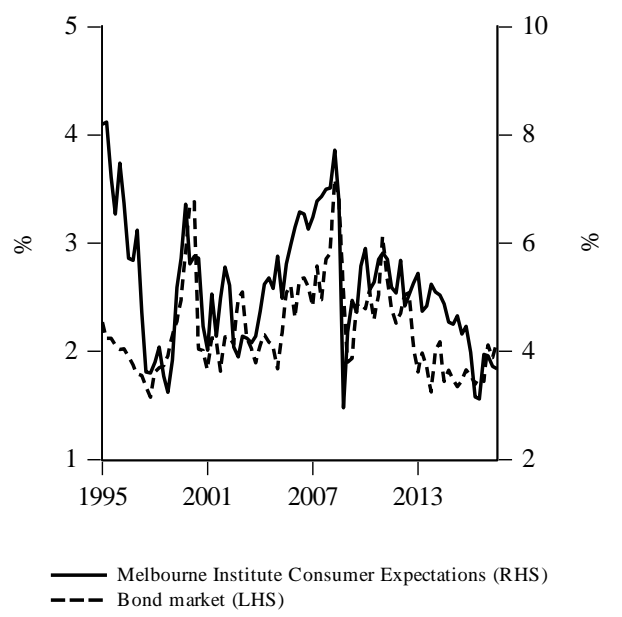

Note: Melbourne Institute measure is a 30 per cent trimmed mean

Sources: Melbourne Institute, Reserve Bank of Australia

Figure 22 Inflation Determinants (Year-Ended, \%)

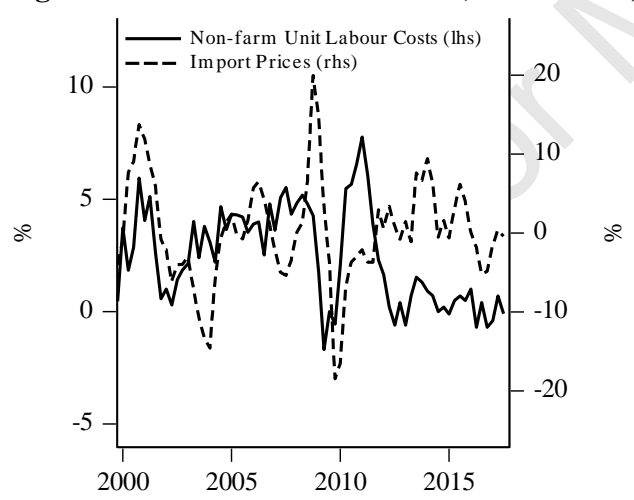

Source: Australian Bureau of Statistics 
Figure 23 Inflation (Year-Ended, \%)

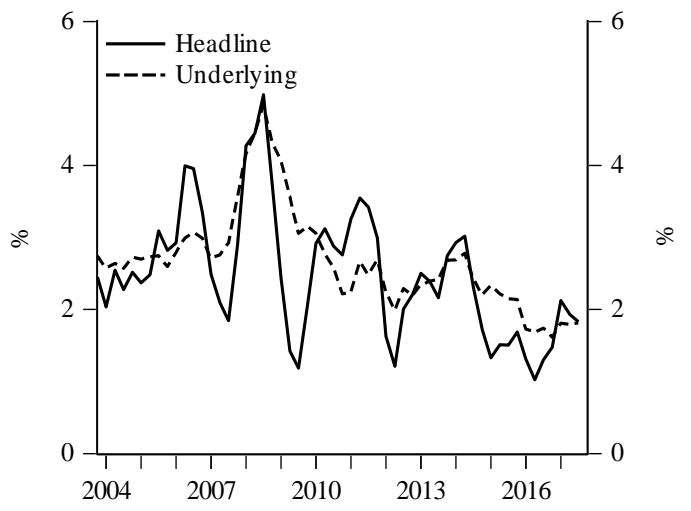

Source: Australian Bureau of Statistics

Figure 24 Indicator Variable Interest Rates

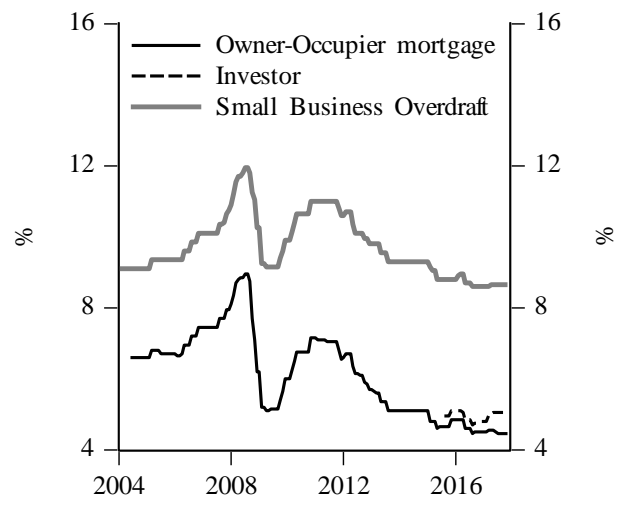

Source: Reserve Bank of Australia

Figure 25 Housing Credit Growth (Year-Ended, \%)

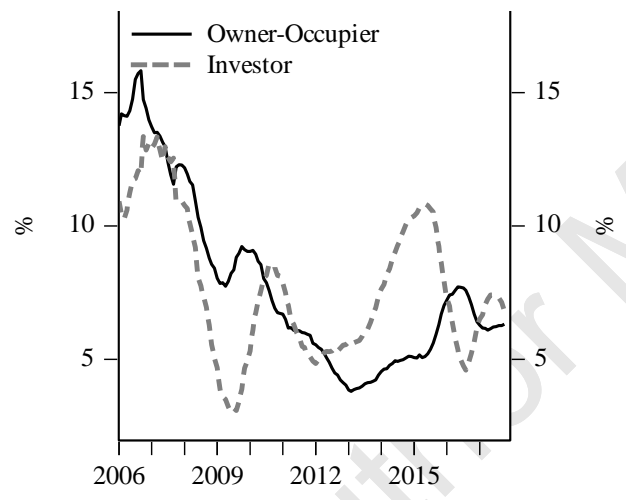

Source: Reserve Bank of Australia 
Figure 26 House and Attached Dwelling Price Growth (Year-Ended, \%)
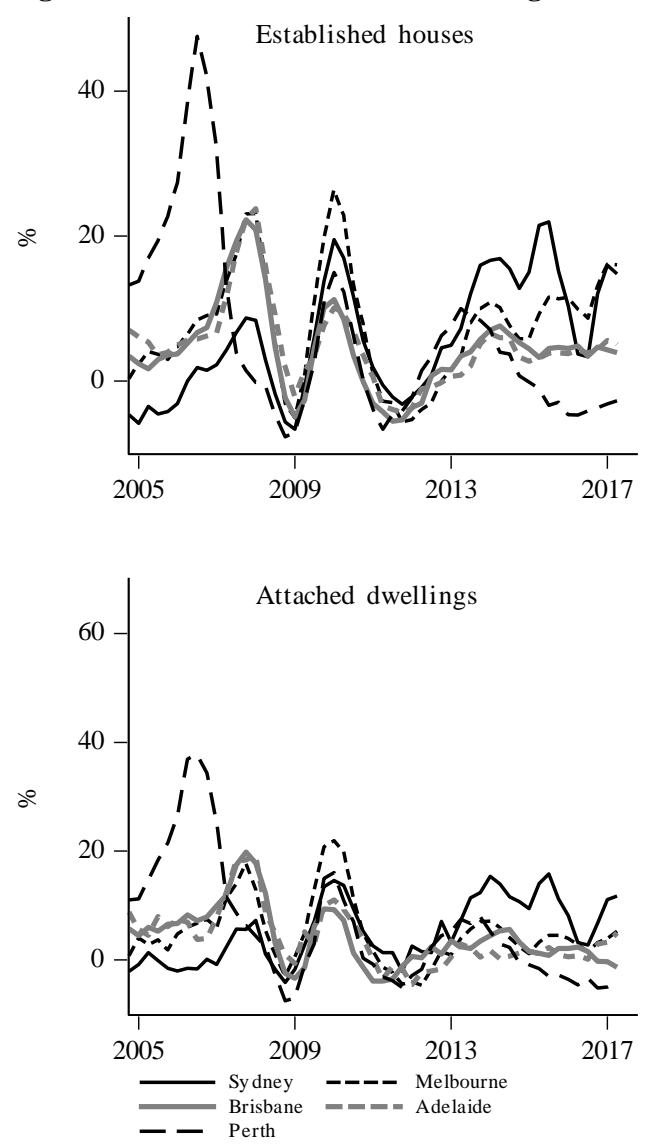

Source: Australian Bureau of Statistics

Figure 27 Mainland States Population Growth (Year-Ended, \%)

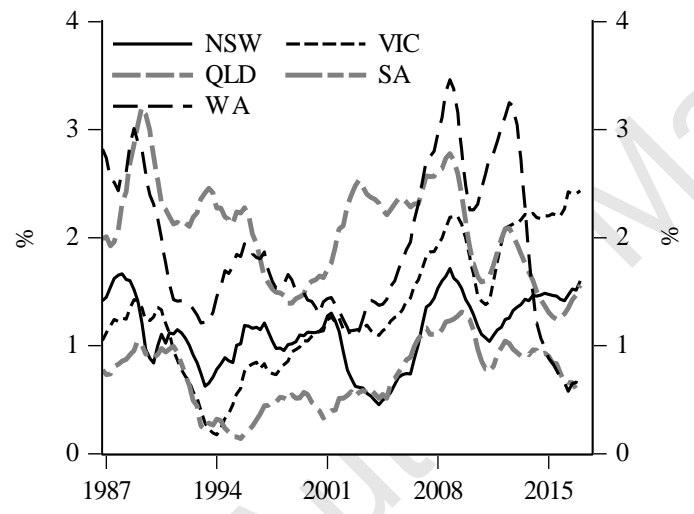

Source: Australian Bureau of Statistics 
Table 1 Indicators of Australian Activity

\begin{tabular}{lcccc}
\hline & & \multicolumn{3}{c}{$2018^{a}$} \\
\cline { 3 - 5 } & $2017^{b}$ & MI $^{c}$ & Low $^{d}$ & High $^{d}$ \\
\hline GDP & 2.4 & 2.9 & 2.0 & 3.2 \\
Consumption & 2.2 & 2.4 & 1.1 & 3.1 \\
Domestic final demand & 2.6 & 2.6 & - & - \\
Unemployment rate & 5.6 & 5.3 & 5.1 & 6.4 \\
Employment growth & 2.1 & 2.0 & - & - \\
Wage Cost Index & 2.0 & 2.4 & 2.2 & 2.8 \\
Headline inflation & 2.1 & 2.3 & 1.8 & 2.6 \\
Underlying inflation & 2.0 & 2.2 & - & - \\
90-day bill rate & 1.7 & 1.9 & 1.7 & 2.4 \\
\hline Notes: (a) Forecasts & & & &
\end{tabular}
(b) Estimates
(c) MI denotes Melbourne Institute
(d) Based on published forecasts in Consensus, November 2017
(e) As at end November 2018

Sources: Melbourne Institute and Consensus: A Digest of

Economic Forecasts 
Table 2 Employment by Industries ('000): Full-Time (FT) and Part-Time (PT)

\begin{tabular}{|c|c|c|c|c|c|c|c|c|c|}
\hline & \multicolumn{3}{|c|}{$\begin{array}{c}\text { Change between } \\
\text { August } 2015 \text { and } \\
\text { August } 2016\end{array}$} & \multicolumn{3}{|c|}{$\begin{array}{c}\text { Change between } \\
\text { August } 2016 \text { and } \\
\text { August } 2017\end{array}$} & \multicolumn{3}{|c|}{$\begin{array}{c}\text { Ratio of } \\
\text { full-time to part-time }\end{array}$} \\
\hline & $F T$ & $P T$ & Total & $F T$ & $P T$ & Total & $\begin{array}{c}\text { August } \\
2015\end{array}$ & $\begin{array}{c}\text { August } \\
2016\end{array}$ & $\begin{array}{c}\text { August } \\
2017\end{array}$ \\
\hline Agriculture, forestry, fishing & -3 & -1 & -4 & 28 & 1 & 29 & 2.6 & 2.6 & 2.9 \\
\hline Mining & -24 & 1 & -23 & -2 & 3 & 0 & 36.6 & 27.8 & 20.6 \\
\hline Manufacturing & 1 & -2 & -1 & 4 & -3 & 1 & 5.2 & 5.3 & 5.4 \\
\hline Electricity, gas, water, waste services & -18 & -2 & -20 & 5 & 3 & 7 & 12.2 & 13.5 & 10.8 \\
\hline Construction & 21 & 2 & 23 & 92 & 11 & 104 & 5.5 & 5.6 & 5.8 \\
\hline Wholesale trade & -7 & 7 & 0 & 10 & -11 & -2 & 4.6 & 4.0 & 4.9 \\
\hline Retail trade & -31 & -7 & -38 & 28 & 9 & 37 & 1.0 & 1.0 & 1.0 \\
\hline Accommodation, food services & 17 & 31 & 49 & 9 & 28 & 38 & 0.7 & 0.7 & 0.7 \\
\hline Transport, postal, warehousing & -10 & 7 & -2 & 32 & -3 & 29 & 3.9 & 3.6 & 4.0 \\
\hline Information media, telecommunications & -4 & -1 & -4 & 4 & 4 & 8 & 4.1 & 4.1 & 3.8 \\
\hline Financial, insurance services & 10 & 5 & 15 & -15 & -2 & -17 & 4.8 & 4.5 & 4.5 \\
\hline Rental, hiring, real estate services & -5 & 7 & 3 & -1 & -7 & -8 & 3.5 & 2.9 & 3.3 \\
\hline Professional, scientific, technical services & 50 & 26 & 76 & -28 & -18 & -46 & 3.5 & 3.3 & 3.4 \\
\hline Administrative, support services & 10 & 23 & 33 & -41 & -2 & -44 & 1.5 & 1.3 & 1.1 \\
\hline Public administration, safety & 25 & 8 & 34 & -14 & -14 & -28 & 4.4 & 4.3 & 4.7 \\
\hline Education, training & 12 & 1 & 13 & 32 & 30 & 62 & 1.5 & 1.5 & 1.5 \\
\hline Health care, social assistance & -7 & 14 & 7 & 100 & 35 & 134 & 1.2 & 1.2 & 1.3 \\
\hline Arts, recreation services & 2 & 10 & 12 & -7 & 14 & 8 & 1.3 & 1.2 & 1.0 \\
\hline Other services & -6 & 18 & 12 & 14 & -2 & 13 & 2.4 & 2.1 & 2.2 \\
\hline Total (industries) & 33 & 149 & 183 & 250 & 75 & 325 & 2.2 & 2.1 & 2.2 \\
\hline
\end{tabular}

Source: Australian Bureau of Statistics, Labour Force, Australia, Detailed, Quarterly, August 2017, Table EQ05

Table 3 Job Creation by Industries and Age Groups ('000)

\begin{tabular}{|c|c|c|c|c|c|c|c|c|}
\hline & \multicolumn{4}{|c|}{$\begin{array}{c}\text { Change between } \\
\text { August } 2015 \text { and August } 2016\end{array}$} & \multicolumn{4}{|c|}{$\begin{array}{c}\text { Change between } \\
\text { August } 2016 \text { and August } 2017\end{array}$} \\
\hline & \multicolumn{8}{|c|}{ Age group (years) } \\
\hline & $15-24$ & $25-44$ & $45-59$ & $60+$ & $15-24$ & $25-44$ & $45-59$ & $60+$ \\
\hline Agriculture, forestry, fishing & 4.4 & -2.0 & -4.7 & -1.4 & 1.5 & -5.0 & 19.3 & 12.9 \\
\hline Mining & 0.9 & -13.4 & -10.3 & -0.1 & -5.1 & 3.8 & 2.1 & -0.5 \\
\hline Manufacturing & -3.1 & 29.5 & -29.3 & 1.4 & 8.9 & -23.0 & 18.3 & -3.1 \\
\hline Electricity, gas, water, waste services & 1.1 & -11.3 & -7.6 & -2.2 & -4.1 & -4.8 & 14.9 & 1.4 \\
\hline Construction & -3.9 & 23.6 & 6.2 & -3.2 & 24.1 & 56.4 & 13.3 & 9.8 \\
\hline Wholesale trade & -9.0 & -0.8 & 6.6 & 2.8 & -7.1 & 5.0 & -0.9 & 1.3 \\
\hline Retail trade & -18.5 & -14.3 & -14.0 & 9.2 & -18.1 & 28.8 & 23.5 & 2.4 \\
\hline Accommodation, food services & 30.2 & 2.0 & 17.0 & -0.5 & 23.0 & 11.1 & 2.4 & 1.0 \\
\hline Transport, postal, warehousing & -4.5 & -6.0 & 4.1 & 4.2 & 13.3 & 21.6 & -2.7 & -3.8 \\
\hline Information media, telecommunications & 6.1 & -13.5 & 3.0 & 0.0 & -2.5 & 9.8 & -0.2 & 1.0 \\
\hline Financial, insurance services & -4.8 & 22.1 & -5.7 & 3.3 & -5.0 & -20.8 & 9.5 & -0.3 \\
\hline Rental, hiring, real estate services & 9.1 & -6.5 & -4.3 & 4.3 & -4.1 & 2.9 & -3.4 & -3.3 \\
\hline Professional, scientific, technical services & 13.3 & 46.1 & 10.3 & 6.5 & -13.5 & -18.0 & -13.3 & -0.9 \\
\hline Administrative, support services & 4.8 & 21.0 & 3.2 & 3.7 & 5.6 & -50.6 & -1.7 & 3.0 \\
\hline Public administration, safety & -3.6 & 7.3 & 27.7 & 2.4 & -0.6 & -15.2 & -14.9 & 2.9 \\
\hline Education, training & 0.7 & -2.2 & 22.6 & -7.9 & 3.8 & 23.2 & 30.3 & 4.8 \\
\hline Health care, social assistance & -8.3 & 9.6 & 9.8 & -4.6 & 25.6 & 93.0 & 12.1 & 3.5 \\
\hline Arts, recreation services & 9.0 & -8.6 & 12.2 & -0.3 & 1.1 & 3.2 & 0.9 & 2.6 \\
\hline Other services & -2.8 & -3.8 & 12.7 & 6.1 & -1.0 & 4.7 & 5.5 & 3.2 \\
\hline Total (industries) & 21.1 & 78.8 & 59.5 & 23.7 & 45.8 & 126.1 & 115.0 & 37.9 \\
\hline Total & \multicolumn{4}{|c|}{183.1} & \multicolumn{4}{|c|}{324.8} \\
\hline
\end{tabular}

Source: Australian Bureau of Statistics, Labour Force, Australia, Detailed, Quarterly, August 2017, Table EQ12 


\section{University Library}

\section{- M M N E R VA A gateway to Melbourne's research publications}

Minerva Access is the Institutional Repository of The University of Melbourne

Author/s:

Robinson, T;Wang, J

Title:

The Australian Economy in 2017-2018: The Importance of Stronger Non-Mining Business Investment Growth

Date:

2018-03-01

Citation:

Robinson, T. \& Wang, J. (2018). The Australian Economy in 2017-2018: The Importance of Stronger Non-Mining Business Investment Growth. AUSTRALIAN ECONOMIC REVIEW, 51 (1), pp.5-20. https://doi.org/10.1111/1467-8462.12257.

Persistent Link:

http://hdl.handle.net/11343/283679 